\title{
IfIISGUC.ORG
}

"iș, GÜç̣" ENDÜSTRi iLișKiLeRi VE inSAN KAYNAKLARI DERGisi

"IS, GUC" INDUSTRIAL RELATIONS AND HUMAN RESOURCES JOURNAL

\section{Use Of Career Strategies, Satisfactions And Psychological Well-Being Among Women Managers And Professionals In Turkey}

\author{
Ronald J. BURKE \\ York University
}

\author{
Mustafa KOYUNCU \\ Nevşehir University \\ Jacob WOLPIN \\ Independent Consultant
}

\section{Nihat ALAYOĞLU}

İstanbul Ticaret University

Temmuz/July 2012, Cilt/Vol: 14, Sayı/Num: 3, Page: 7-18

ISSN: 1303-2860, DOI: 10.4026/1303-2860.2012.0203.x

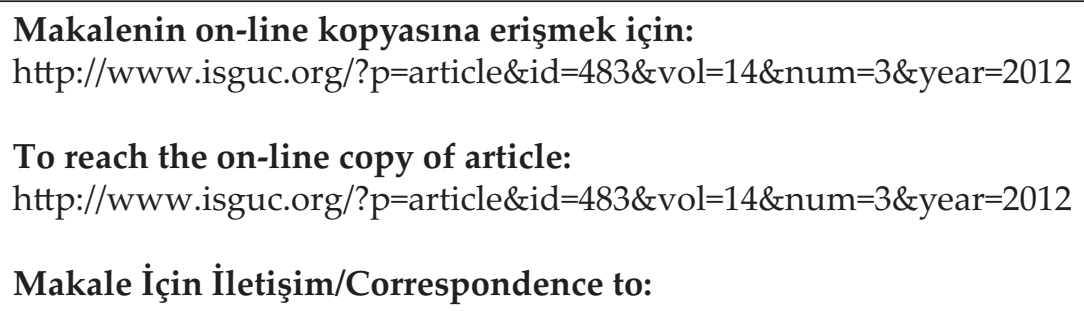


(c) 2000- 2012

“İşGüç” Endüstri İlişkileri ve İnsan Kaynakları Dergisi

"İşGüç" Industrial Relations and Human Resources Journal

Temmuz/July 2012, Cilt/Vol: 14, Say1/Num: 3

ISSN: 1303-2860, DOI: 10.4026/1303-2860.2012.0203.x

İş,Güç, Endüstri İlişkileri ve İnsan Kaynaklanı Dergisi, yılda dört kez yayınlanan hakemli, bilimsel elektronik dergidir. Çalışma hayatına ilişkin makalelere yer verilen derginin temel amacı, belirlenen alanda akademik gelişime ve paylaşıma katkıda bulunmaktadır.

İş, Güç, Endüstri İlişkileri ve İnsan Kaynakları Dergisi, 'Türkçe' ve 'İngilizce' olarak iki dilde makale yayınlanmaktadır. Dergi ulusal ve uluslar arası birçok indekste taranmaktadır. (CABELLS DIRECTORY, EBSCO SOCINDEX , INDEX ISLAMICUS, INDEX COPERNICUS, WORLDWIDE POLITICACAL SCIENCE ABSTRACTS, SOCIOLOGICAL ABSTRACT, ULAKBIMM SOSYAL BİLIMLER VERİTANI, ASOS INDEX)

\section{Editör/Editor-in-Chief}

Aşkın Keser (Uludă̆ University)

Editör Yardımcılarn/Co-Editors

K.Ahmet Sevimli (Uludağ University)

Gözde Yilmaz (Marmara University)

Uygulama/Design

Yusuf Budak (Kocaeli Universtiy)

\section{Tarandiğı Indeksler}

ASOS INDEX

\section{CABELLS DIRECTORY}

EBSCO SOCINDEX

Index ISLAMICUS

Index COPERNICUS

Sociological Abstract

ULAKBİM Sosyal Bilimler Veritan

Worldwide Political Science Abstracts
Yayın Kurulu / Editorial Board

Dr. Erdem Cam (ÇASGEM)

Dr. Zerrin Firat (Uludă̆ University)

Doç. Dr. Aşkın Keser (Uludağ University)

Prof. Dr. Ahmet Selamoğlu (Kocaeli University)

Yrd. Doç. Dr. Ahmet Sevimli (Uludă̆ University)

Doç. Dr. Abdulkadir Șenkal (Kocaeli University)

Doç. Dr. Gözde Yilmaz (Marmara University)

Dr. Memet Zencirkıran (Uludă̆ University)

Uluslararası Danışma Kurulu / International Advisory Board Prof. Dr. Ronald Burke (York University - CA)

Assoc. Prof. Dr. Glenn Dawes (James Cook University - AU)

Prof. Dr. Jan Dul (Erasmus University - NL)

Prof. Dr. Alev Efendioğlu (University of San Francisco - USA)

Prof. Dr. Adrian Furnham (University College London - UK)

Prof. Dr. Alan Geare (University of Otago - NZ)

Prof. Dr. Ricky Griffin (TAMU-Texas AEM University - USA)

Assoc. Prof. Dr. Diana Lipinskiene (Kaunos University - LT)

Prof. Dr. George Manning (Northern Kentucky University - USA)

Prof. Dr. William L. Murray (University of San Francisco - USA)

Prof. Dr. Mustafa Özbilgin (Brunel University - UK)

Assoc. Prof. Dr. Owen Stanley (James Cook University - AU)

Prof. Dr. Işık Urla Zeytinoğlu (McMaster University - CA)

Ulusal Danışma Kurulu / National Advisory Board

Prof. Dr. Yusuf Alper (Uludă̆ University)

Prof. Dr. Veysel Bozkurt (İstanbul University)

Prof. Dr. Toker Dereli (Işık University)

Prof. Dr. Nihat Erdoğmuş (Şehir University)

Doç. Dr. Mustafa Kurt (Yalova University)

Prof. Dr. Ahmet Makal (Ankara University)

Prof. Dr. Süleyman Özdemir (İstanbul University)

Prof. Dr. Ahmet Selamoğlu (Kocaeli University)

Prof. Dr. Nadir Suğur (Anadolu University)

Prof. Dr. Nursel Telman (Maltepe University)

Prof. Dr. Cavide Uyargil (İstanbul University)

Prof. Dr. Engin Yildirm (Constitutional Court of Turkey)

Doç. Dr. Arzu Wasti (Sabancı University)

Dergide yayınlanan yazılardaki görüşler ve bu konudaki sorumluluk yazarlarma aittir.

Yayınlanan eserlerde yer alan tüm içerik kaynak gösterilmeden kullanılamaz.

All the opinions written in articles are under responsibilities of the outhors.

The published contents in the articles cannot be used without being cited. 


\title{
Use Of Career Strategies, Satisfactions And Psychological Well-Being Among Women Managers And Professionals In Turkey*
}

\author{
Ronald J. BURKE \\ York University
}

\author{
Mustafa KOYUNCU \\ Nevşehir University \\ Jacob WOLPIN \\ Independent Consultant
}

\author{
Nihat ALAYOĞLU \\ İstanbul Ticaret University
}

\begin{abstract}
The concept of career self-management gained currency in the early 1980s. It proposed that individuals could use career strategies to influence their career progress. Empirical support for this proposition has been low or mixed. The present study examines the relationship of use of career strategies and work and well-being outcomes in a sample of 143 women managers and professionals working in Istanbul Turkey. The vast majority worked in the public sector. Respondents indicated only limited use of these career strategies. Hierarchical regression analyses, controlling for both personal demographics and work situation characteristics were undertaken to determine the relationship of use of various career strategies and these outcomes. Use of career strategies had no relationship with any of our outcome measures. It may be that use of career strategies is more likely to be associated with work and well-being outcomes among women who are career oriented and work in organizational cultures more supportive of women and their career prospects.
\end{abstract}

Key words: Career, Career Strategies, Well-being, Satisfaction

\footnotetext{
* Preparation of this manuscript was supported in part by York University, Nevsehir University and Istanbul Ticaret University. We thank the four organizations that participated in the data collection and our respondents
} 


\section{Introduction}

The concept of career self-management started receiving both practical and research attention in the early 1980s (Hall, 1976, 1996) It suggested that individuals were more likely to advance their careers (e, g., be promoted) if they engaged in behaviours identified as career strategies (Gould \& Penley, 1984). Gould and Penley identified seven career strategies based on their review of the career self-management writing. These were: creating career opportunities, extending work involvement, self-nomination/self-presentation, seeking career guidance, networking, opinion conformity and other means of enhancing or ingratiating oneself with one's manager. Since then, researchers have begun to investigate correlates of career strategies and their use.

Gould and Penley (1984) developed a measure of use of these career strategies and considered the relationship between their use and career progress. They reported, based on respondents working in the public sector, that managers made greater use of career strategies than did non-managers, and managers promoted in their careers made greater use of them than did managers who had not. Males and females were generally similar though females indicated a greater use of seeding guidance from others and males made greater use of extending their work investment by working harder and longer. Their respondents worked in the public sector.

McKeen and Burke (1993) investigated use of career strategies in a large sample of Canadian managerial and professional women. This sample did not use the Gould and Penley career strategies very often. Few demographic and work situation characteristics were associated with use of them as well. But managerial and professional women using more career strategies indicated higher levels of job and career satisfaction and job involvement.

Burke, Divinagracia and Mamo (1998) considered use of these career strategies in a sample of 200 Filipino managerial and professional women working in a variety of industries. These women made considerable use of these strategies, making greater use of those internal than external to their organization. Women using more career strategies worked more extra hours per week and took part in more training and development activities. In addition, these women were more satisfied with their careers and indicated more optimistic future career prospects.

But other studies have shown no relationship between use of career strategies and careers success. Yean and Yahya (2008), in a study of 185 employees from a Malaysian manufacturing organization, reported almost no relationship, using a measure of career strategies developed by Lau and Pang (2000). Abraham (2011) found, in a sample of employees in Indian banks, only a weak relationship of use of career strategies and career outcomes, using a measure of career strategies that she created for the research. And Noe (1996, in an Americans study, reported no relationship between employee use of career management strategies and manager's ratings of their job performance.

Thus research evidence on the relationship of use of career strategies and various subjective and objective indicators of career success is mixed. Possible explanations for these mixed results include studies being conducted in countries having different values and beliefs about women and work, different values and beliefs about self-promotion by women, and different levels of overall support for women in the workplace,. Studies involving women managers and professionals have reported both high use of career strategies in the Philliines (Burke, Divnigracia \& Mamo, 1998) and low use of these same career strategies in Canada (McKeen \& Burke, 1993).

Morrison, White and Van Velsor (1987, 1992) noted that managerial and professional women in their American samples could not be too assertive in promoting themsel- 
ves. In addition, women have made greater progress in both entering managerial and professional jobs and have achieved more upward mobility in some countries than in others (Davidson \& Burke, 2004, 2011) so the context for women's use of career strategies likely differs as well. It is not clear how these factors would affect both the use of career strategies by women and their potential benefits.

\section{Woman in management in Turkey}

This study examined the relationship of the use of career strategies and work and psychological well-being outcomes in a sample of managerial and professional women in Turkey. There has been both reviews on the status of women in Turkey (Kabasakal,

Aycan, Karakas \& Maden, 2011; Kabasakal, Aycan \& Karakas, 2004; United Nations Development Programme, 2008) as well as a small but growing body of research findings (Aycan, 2004; Aycan \& Eskin, 2005;Ufek \& Ozgen, 2001; Koyuncu, Burke \& Fiksenbaum, 2006; Burke, Koyuncu \& Fiksenbaum, 2008; Ozbilgin \& Woodward, 2004; Woodward \& Ozbilgin, 1999).

The reviews are particularly informative. The work of Kabasakal and her colleagues $(2004,2011)$ indicates slow progress of women's advancement into both the workforce and in managerial and professional positions There are an increasing number of women entering universities but women still concentrate in areas of study that have been typically seen as feminine avoiding the sciences technology and business. Government legislation exists to support the advancement of women but it is not clear the extent to which this legislation is enforced. Government organizations offer training for women in fields such as entrepreneurship. Women have fared particularly well in some professions such as education and university professorships. Private sector organizations, however, rarely undertake initiatives that target the selection, development and ad- vancement of women. In a comparison of thirteen countries, a United Nations Development Programme (2008) study showed that Turkey ranked last in the number of positions held by women in management, as legislators, and as union officials.

\section{Objectives of the research}

This study considered the use of career strategies and indicators of work and career satisfaction and psychological well-being in a sample of Turkish managerial and professional women.

Two general hypotheses, building on previous work, were examined in this research.

1. Female managers and professionals reporting greater use of career strategies would report higher levels of work satisfaction.

2. Female mangers and professionals reporting greater use of career strategies would report higher levels of psychological well-being

\section{Method}

\section{Procedure}

Four organizations located in Istanbul Turkey were contacted, the purpose of the study explained, and access to women holding full time managerial and professional jobs was requested. Data were collected using anonymously completed questionnaires. The four institutions were: the Istanbul Chamber of Commerce (ICC),, the Istanbul Commodity Exchange (ICE), the Foreign Economic Relations Board (FERB) and the Economic Development Foundation (EDF). Each of these organizations has a board of directors made up mainly of men and they provide services to the business community. All respondents held jobs offering opportunities for promotion and were at various organizational levels (e. g., executive, director ,managers, auditors, inspectors, content experts, and consultants. Respondents in the first two organizations (ICC, ICE received hard copies of the questionnaire, respondents in the other two organizations (FERB, $\mathrm{EDF})$ received the questionnaire electroni- 
cally. Data were collected in September through November 2011.A total of 210 females were invited to participate and 143 did so, a response rate of 68 percent. Most respondents were employed with the ICC (79\%).

\section{Respondents}

Table 1 presents demographic characteristics of the sample $(\mathrm{N}=143)$. Most were between 31 and 40 years of age $(49 \%)$, about half were married (50\%), about half had children (51\%) Most had a Bachelor's degree
(53\%), worked 40 hours per week (68\%), most earned between US\$15,000 and US\$21,999 per week (43\%), were in lower management $(36 \%)$, had supervisory duties $(78 \%)$, worked in the public sector $(92 \%)$, had been working for their organization 5 years of less (32\%) and in their present jobs between 3 to 5 years (32\%), had 6 to 10 subordinates $(34 \%)$, and worked in organizations over 100 people $(78 \%)$, these respondents working for the same large public sector organization.

Table 1

Demographic Characterics of the Sample

\begin{tabular}{|c|c|c|c|c|c|}
\hline Age & $\underline{\mathrm{N}}$ & $\underline{\%}$ & $\underline{\text { Marital Status }}$ & $\underline{\mathrm{N}}$ & $\underline{\%}$ \\
\hline 30 or younger & 40 & 28.0 & Married, cohabiting & 72 & 50.3 \\
\hline $31-40$ & 70 & 48.9 & Single & 71 & 49.7 \\
\hline $41-50$ & 28 & 19.6 & & & \\
\hline \multirow[t]{2}{*}{51 or older } & 5 & 3.5 & Education & & \\
\hline & & & High school & 24 & 16.8 \\
\hline$\underline{\text { Parental status }}$ & & & Bachelors & 76 & 53.1 \\
\hline Have children & 73 & 51.1 & Masters & 43 & 30.1 \\
\hline \multirow[t]{2}{*}{ No children } & 70 & 48.9 & & & \\
\hline & & & $\underline{\text { Income }}$ & & \\
\hline Work hours & & & $\$ 15.000$ or less & 21 & 14.7 \\
\hline 39 or less & 5 & 3.5 & $\$ 15.000-\$ 21.999$ & 62 & 43.4 \\
\hline 40 & 97 & 67.8 & $\$ 22.000-\$ 28.999$ & 32 & 22.4 \\
\hline $41-50$ & 39 & 25.3 & $\$ 29.000$ or more & 28 & 19.6 \\
\hline \multirow[t]{2}{*}{51 or more } & 2 & 1.4 & & & \\
\hline & & & Organizational level & & \\
\hline Organizational tenure & & & Non-management & 32 & 22.4 \\
\hline 5 years or less & 46 & 32.2 & Lower management & 52 & 36.4 \\
\hline $6-10$ & 34 & 23.7 & Middle management & 49 & 32.9 \\
\hline $11-15$ & 34 & 23.8 & Senior management & 12 & 8.4 \\
\hline $16-20$ & 12 & 6.4 & & & \\
\hline \multirow{2}{*}{21 or more } & 17 & 11.9 & $\underline{\text { Supervisory duties }}$ & & \\
\hline & & & Yes & 111 & 77.6 \\
\hline Iob Tenure & & & No & 32 & 22.4 \\
\hline $1-2$ years & 44 & 30.8 & & & \\
\hline $3-5$ & 46 & 32.1 & $\underline{\text { Sector }}$ & & \\
\hline $6-10$ & 23 & 16.1 & Private & 11 & 7.7 \\
\hline $11-20$ & 23 & 16.1 & Public & 132 & 92.3 \\
\hline$\underline{\text { Organization size }}$ & & & $\underline{\text { Number of subordinates }}$ & & \\
\hline 100 or less & 31 & 22.4 & 0 & 32 & 32.4 \\
\hline \multirow[t]{6}{*}{100 or more } & 112 & 77.6 & $1-5$ & 20 & 14.0 \\
\hline & & & $6-10$ & 34 & 33.7 \\
\hline & & & $11-15$ & 14 & 9.8 \\
\hline & & & $16-20$ & 14 & 9.8 \\
\hline & & & $21-25$ & 14 & 9.8 \\
\hline & & & 26 or more & 15 & 10.5 \\
\hline
\end{tabular}




\section{Measures}

Personal demographics (e.g., age, gender, education, marital and parental status) were measured by single items.

Work situation characteristics were also measured by single items. (sector, organizational level, organizational and job tenure, organizational size)

\section{Use of career strategies}

Career strategies was measured by an eight item scale $(\alpha=.72)$, the seven items from the original Gould and Penley (1984) measures with the addition of an eighth. Respondents indicated how often they had engaged in each career strategy during the past year (1-never, 3=occasionally; $5=$ always). Sample items included: ":Worked harder when you knew the results would be seen by your superiors." And Obtaiend broad bsed work experience in your organization."

\section{Work outcomes}

Four work outcomes were included.

Job satisfaction was measured by six items ( $\alpha .93$ )developed by Kofodimos (1993). One item was "I feel challenged by my work."

Career satisfaction was assessed y three items $(\alpha=.70)$ developed by Greenhaus, Parasuraman and Wormley (1990). An item was "I am satisfied with the success I have had in my career"..

Career progress was also measured by a three item scale $(\alpha=.52)$ developed by Greenhaus, Parasuraman and Wormley (199)). One item was "I have very good prospects for promotion in this organization."

Intent to quit was measured by two items $(\alpha=.76)$ used previously by Burke (1991). An item was "Are you currently looking for a different job I a different organization? (yes/no).

\section{Psychological well-being}

Two aspects of psychological health were included.

Stress was measured by a 9 item scale $(\alpha=.80)$ developed by S[pence and Robbins (1992). Respondents indicated their agreement with each item on the same 5 point Likert scale. A sample item was "I am under a great deal of stress at work."

Emotional exhaustion was assessed by a 9 item scale $(\alpha=, 91)$ developed by Maslach, Jackson and Leiter (1996) One item was "I feel emotionally drained from my work."

\section{Results}

\section{Descriptive statistics}

Table 2 shows the frequency of usage of each of the eight career strategies. Mean values ranged from a high of 3.9 (obtained broad based work experience in your organization) to a low of 2.4 (took work home with you, sought career guidance from experienced persons inside the organization, sought carer guidance from experienced persons outside the organization) The total scores was 24.0 , s.d. $=5.59, \mathrm{n}=135$.. The mean value for all eight career strategies was 3.0 indicating only occasional use of them.

Personal demographics, work situation characteristics and use of career strategies

Correlations were computed between thirteen personal demographic and work situation characteristics (e.g,, age, level of education, income, marital status, job tenure, number of subordinates) and self-reported use of career strategies. Only two of these thirteen correlations $(15 \%)$ reached statistical significance at the .05 level of confidence Managerial and professional women who were more highly educated and earned more income made greater use of these career strategies ( $\mathrm{rs}=.29$ and .21, respectively).

\section{Hierarchical regression analyses}

Hierarchical regression analyses were undertaken in which the various work and well-being outcomes were separately reg- 
Table 2

DUse of Career Strategies

\section{Career Strategies}

1. Worked harder when results seen by superiors.

2. Contacts inside organization to obtain information.

3. Obtained broad work experience

4. Took work home.

5. Contacts outside organization to obtain information.

6. Made boss aware of wanted assignments.

7. Sought career guidance inside the organization.

8. Sought career guidance outside the organization.

$\mathrm{Ns}=135$ on use of each career strategy

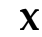

SD

1.45

.98

.93

1.24

1.17

1.17

1.20

1.30

2.4 ressed on three blocks of predictors. The first block of predictors included four personal demographic characteristics (age, marital status, parental status, level of education. The second block of predictors included four work situation characteristics: organizational level, supervisory duties, organizational tenure, and job tenure. The third block of predictors included the measure of se of career strategies. When a block of predictors accounted for a significant amount or increment $n$ explained variance with a given outcome measure $(\mathrm{p}<.05)$, individual items or measures within these blocks having significant and independent relationships with this outcome were then determined $(\mathrm{p}<.05)$. This approach controls for the relationship of both personal demographics and work situation characteristics with a given outcome before considering the relationship of the predictors of interest, in this case the measures of work and family interference.

\section{Use of career strategies and work outcomes}

Table 3 presents the results of hierarchical regression analyses in which the four work outcomes were separately regressed on the three blocks of predictors (personal demographics, work situation characteristics, career strategies). The following comments are offered in summary. Use of career strategies failed to account for a significant increase in explained variance in any of the four analyses. Managerial and professional women having shorter job tenures, and managerial and professional women at higher organizational levels, indicated higher levels of career satisfaction $(\mathrm{Bs}=-.29$ and .30 , respectively).

Use of career strategies and psychological well-being

Table 4 shows the results of hierarchical regression analyses in which two indicators of psychological well-being were separately regressed on the three blocks of predictors. The following comments are offered in summary Use of career strategies failed to account for a significant increment in explained variance on either indicator Managerial and professional women having supervisory duties, and managerial and professional women at lower organizational levels reported higher levels of exhaustion (Bs=.42 and .30 , respectively). 
Table 3

Use of Career Strategies and Work Outcomes

Work Outcomes

Iob satisfaction ( $\mathrm{n}=132$ )

Personal demographics

Work situation characteristics

Career strategies

Career satisfaction ( $\mathrm{n}=133$ )

Personal demographics

Work situation characteristics

Job tenure (-.29)

Organizational level (.30)

Career strategies

Career prospects ( $\mathrm{n}=133)$

Personal demographics

Work situation characteristics

Career strategies

Intent to quit ( $\mathrm{n}=135)$

Personal demographics

Work situation characteristics

Career strategies

$\begin{array}{rrrr}\underline{\mathrm{R}} & \underline{\mathrm{R}^{2}} & \frac{\Delta \mathrm{R}^{2}}{\mathrm{~N}} & \underline{\mathrm{P}} \\ .21 & .05 & .05 & \mathrm{NS} \\ .34 & .12 & .07 & .05 \\ .35 & .12 & .00 & \mathrm{NS}\end{array}$

.18

.03

$.03 \quad$ NS

.36

.13

.10

.05

.36

.13

.00

NS

$\begin{array}{llll}.19 & .04 & .04 & \text { NS } \\ .30 & .09 & .05 & \text { NS } \\ .30 & .09 & .00 & \text { NS }\end{array}$

$\begin{array}{llll}.22 & .05 & .05 & \text { NS } \\ .25 & .06 & .01 & \text { NS } \\ .26 & .07 & .01 & \text { NS }\end{array}$

\section{Table 4}

Use of Career Strategies and Psychological Well-Being

Psychological Well-being

Exhaustion $(\mathrm{n}=128)$

Personal demographics

$\begin{array}{rrrr}\underline{\mathrm{R}} & \underline{\mathrm{R}^{2}} & \underline{\Delta \mathrm{R}^{2}} & \underline{\mathrm{P}} \\ .16 & .03 & .03 & \mathrm{NS} \\ .33 & .11 & .08 & .05\end{array}$

Work situation characteristics

Supervisory duties (.42)

Organizational level (-.30)

Career strategies

Stress(n=130)

Personal demographics

Work situation characteristics

Career strategies
.22

.27

.27

$\begin{array}{lll}.04 & .04 & \text { NS } \\ .07 & .03 & \text { NS } \\ .07 & .00 & \text { NS }\end{array}$




\section{Discussion}

Our findings failed to provide support for our two hypotheses. Use of career strategies in a sample of managerial and professional women Turkey, mostly employed in the public sector, was unrelated to both work outcomes and indicators of psychological health (see Tables 3 and 4). In addition, the sample as a whole made relatively little /low use of these career strategies, on average, using them only occasionally.

We can only speculate as to why this occurred. Some possible explanations would include: the sample on the whole made relatively little use of the career strategies investigated here, the vast majority of women in the sample worked in the public sector which may have had other factors as being important to career success and progress(e.g., seniority), the sample in general was not particularly interested in career advancemet0-most working 40 hours per week,

Interestingly, other research has also found low or limited support for uses of a variety of career strategies and different work and career outcomes (Abraham, 2011; Noe, 1996; Yean \& Yahya, 2008)

\section{Limitations of the research}

This study, typical of most research, has some limitations. First, all data were collected using self-report questionnaires raising the possibility of response set tendencies. Second, all data were collected at one point it time making it impossible to consider cause and effect relationships. Third, some of the measures had levels of internal consistency reliabilities slightly below the generally accepted standard of .70. Fourth, the sample contained mostly women working in the public sector; in addition this sample may not be reflective of all women working in the public sector. Fifth, there may be other career strategies more relevant to women in management in Turkey than the ones identified in the American study (Gould \& Penley, 1984)

\section{Future research directions}

Several promising future research directions can be identified. First, a qualitative study using interviews and/or focus groups of Turkish managerial and professional women might identify additional career strategies that fit their personal circumstances, culture and workplaces, which ones they have used and why they did not use others. Second, it seems important to determine the career aspirations of these managerial women. Career strategies are more likely to be used by women interested in career advancement. A related research effort might be focussed on women that have in fact achieved more senior executive levels in their organizations. Perhaps sampling women in the private sector would also prove enlightening. Finally, considering culture and country differences in values might serve to indicate the context in which use of career strategies would be associated with career progress and those in which use of career strategies would not. 


\section{References}

Abraham,S. (2011) Individual career management and career satisfaction among employees in Indian banks. International Conference on Technology and Business Management, March.

Aycan, Z. (2004) Key success factors for women in management in Turkey. Applied Psychology: An International Review, 53, 453-477.

Aycan, Z., \& Eskin, M. (2005) Childcare, spousal and organizational support in predicting work-family conflict for females and males in dual-earner families with pre-schcool children. Sex roles, 53, 453-471.

Burke, R. J. (1991) Early work and career experiences of female and male mangers and professionals: Reasons for optimism? Canadian Journal of Administrative Sciences, 8, 224-230.

Burke, R. J \& Koyuncu, M. (2012) Women in management in Turkey. In M. Paludi (ed.) Women and management. Global issues and promising solutions. Santa Barbara, CA: ABC-CLIO Inc.in press.

Burke, R. J., Koyuncu. M., \& Fiksenbaum,. L: (2008) Still a man's world: Implications for managerial and professional women in a Turkish bank. Gender in Management: An International Journal. 23, 278290.

Burke, R. J,., Divinagracia, L., \& Mamo, E. (1998) Use of career strategies by Filipino managerial women. Women in Management Review, 13, 217-220.

Gould, S. \& Penley, L. F. (1984) Career strategies and salary progression: a study of their relationships in a municipal bureaucracy. Organizational Behavior and Human Performance, 34, 244-265.
Greenhaus, J. H.,, Parasuraman, S., \& Wormley, W. (1999) Organizational experiences and career success of black and while managers. Academy of Management Journal, 33, 64-86.

Hall, D. T. (1996) The career is dead. Long live the career,. San Francisco: JosseyBass

Hall, D. T. (1976) Careers in organizations. Pacific Pallisades, CA: Goodyear Publishing Company

Kabasakal, H., Aycan, Z., Karakas,F., \& Maden, C. (2011) Women in management in Turkey. In M. J. Davidson \& R. J. Burke (eds.) Women in management worldwide: Progress and prospects. Surrey: Gower Publishing. pp 317-339.

Kabasakal, H., Aycan, Z., \& Karakas, F. (2004) Women in management in Turkey. In M. J. Davidson \& R. J. Burke (eds.) Women in management worldwide: Facts, figures and analysis. Aldershot: Ashgate Publishing. pp 273-293.

Kofodimos, J. (1993) Balancing act. San Francisco: Jossey-Bass

Lau, A. \& Pang,M. (2000) Career strategies to strengthen graduate employees' employment position in Hong Kong. MCB University Press, 42, 135-145.

Koyuncu, M., Burke, R. J., \& Fiksenbaum, L. (2006) Work experience and satisfaction of male and female professors in Turkey: Signs of progress? Equal Opportunities International, 25, 38-47.

Maslach, C. Jackson, S. E., \& Leiter,M. P. (1996) Maslach Burnout Inventory, 3rd ed. Palo Alto, CA: Consulting Psychologists Press. 
McKeen, C. A,. \& Burke, R. J., (1993) Use of career strategies by managerial and professional women. International Journal of Career Management, 5, 19-24.

.Morrison, A. M., White, R. P., \& Van Velsor, E. (1987) Breaking the glass ceiling. Reading, MA: Addison-Wesley.

Morrison, A. M., White, R. P., \& van Velsor, E. (1992)Breaking the glass ceiling. Updated edition. Readidng, MA: AddisonWesley.

Noe, R. A. (1996) Is career management related to employee development and performance? Journal of Organizational behaviour, 17, 119-133.

Ozbilign, M. \& Woodward, D.(2004) “:Belonging" and "otherness": sex equality in banking in Turkey and Britain. Gender, Work and Organizations, 11, 668688.

Spence, J. T., \& Robbins, A. S. (1992) Workaholism: Definition, measurement and preliminary results. Journal of Personality Assessment, 58, 160-178.

Ufuk, H. \& Ozgen, O. (2001) The profile of women entrepreneurs: A sample from Turkey. International Journal of consumer Studies, 25, 299-308.

United Nations Development Programme (2008 ) Human development report 2007-2008. New York: Oxford University Press.

Woodward, D. \& Ozbilgin, M (1999) Sex equality in the financial services sector in Turkey and the UK. Women in Management Review, 14, 325-332.

Yean, T. F., \& Yahya, K. K.(2008) The relationship between career strategies and career success. International Journal of Management Studies, 15, 85-101. 